\title{
Reengineering some uncertainties about communicational relationships
}

\author{
Ştefan Vlăduţescu \\ University of Craiova, 13 A. I. Cuza Street, 200585, Craiova, Romania \\ E-mail address: stefan.vladutescu@yahoo.com
}

\section{ABSTRACT}

The impulse to start the current research is represented by the a certainme hat in universe of communication there is a persistence of uncertainties regardi place an functions of communicational relationship in the processes of communicati The dy takes into account the fact that in the nuclear center of communication there io commun ional relationship. The investigation focuses on revealing the conceptual art culations for und standing the idea of communicational relationship. We emphasize the fact at, on the first level, communication is a voluntary social involvement, an intentional existenti manifestatic h. The so-called involuntary aspects of communication are moments of loss of contro genera ng meanings. There cannot be communication without a will for communicat The mean the first level of human will and desire for communication. The second level i. th cage. Communication itself appears as an integrative third level of human will for comm nic an he help the emergence to be seen and delineate the criteria for the comnrehension of communicational relationships: existential manifestation, the classes of con mun tors (ac rs, agents, actants, interactants, transactants), transactivity (transactional cri n), nd repet on (iteration). The conclusion is that the communicational relationshis is onal-iterative, transactional and life-existential meaningful manifestation.

Keywords: communic on un tainties; lommunicational relationship; life manifestation

\section{INTRODUL ON}

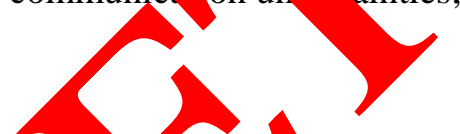

Hum n commy ricational relationships constitute the ontological armature of society. It does a society without relational network. "People, assert Dumitru Otovescu, Florin toiu and Radu Petcu, consume their social life relating" (Otovescu, Păsătoiu \& Petcu, 20 , p. 340). There enter in the human relationship sphere both the personal relationship, and the interpersonal relationship (professional, organizational, interethnic etc.) Human relationships are understood by almost all specialists as being social relationships (Barker, 2003; Barker, 2012). A primary premise that leads to this inference is that the human being is a communicational being. As conscious entity emerging inside the social and developed under this circumstance, the human being is communicationally impregnated. Therefore, his relationships are also communicationally impregnated, either directly, or indirectly. A normal exigency of General Communication Science contends that the human relationships that are indirectly impregnated by the communicational trait are to be analyzed 
as personal relationships. Their sphere, without being insignificant, is however reduced, and their specific is apodictic. However, wider scientific resonance is communicational relationship. If the human relationships constitute the ontological pillar of society, the communicational relationships constitute the radiant axis of sociology.

\section{FOUR DEFINITIONAL CRITERIA FOR A STANDARD COMMUNICATIONAL RELATIONSHIP}

We consider that it is necessary a systematization of the meanings of stan d „communicational relationship”, because this is a nuclear sociological concer Flie Bădes considers, in truth, that „social relationships represent the central concnnt o aciolog, (Bădescu, 2010, p. 279). Similarly, we say, communicational relationshi is a nuclè onc pt of communication.

By definition, the communicational relationship meets fo $\mathrm{r}$ a, pre nts four aspects. The four standard criteria of communicational rel ionship the existential manifestation, the classes of communicators/the number of co nunicators ctors, agents, actants, interactants, transactants), transactivity (transac onal terion), and repetition (iteration). A communicational relationship is an mopersonar mive, transactional existential meaningful manifestation. If the exister ial meaningful panifestation does not repeat, then we speak of communicational contact u Plessis, 2701; Du Plessis, 2005). The existential contact is a repetitive stage of an existent neaningf 1 manifestation.

\section{a) The existential meaningful aspect}

An existential meaningful manifestatio Fir people generate meanings. Human beings and only human beings generate mea ngs. Human life is a universe of meanings. After thousands of years of cocon uction fmeaning and message processing, in the communicators' mind the me is uilt irrep essibly. It cannot not stir meanings, it is not possible not to assign me ing ossible not to estimate a message. However, despite the first axiom the Palo o School (non-communication is impossible), we see that non-communicat on ossible. 0 munication is not given, but it is constructed. It is a higher level and itris uilt th pre-communicative elements, as meanings. The level of the infra-meanings and the level o created meanings, discovered or assigned constitute the zero level, th auton tic level/Communication emerges as significant interaction (indicial, indicator, sen signal ic, iconic, symbolic, and symptomatic). There is a joining and sharing mean of ational or emotional order: thoughts, ideas, knowledge, feelings, opir ons, ormatio the essence of communication - "sharing" - means sharing meanings. Thu mp hension/and the sharing as defining approaches of the communicational process refer eanıngs. Comprehensibility is an ontological principle. Communication can remain only at e level of comprehension. It can advance towards higher levels of "significaty nality": trust, power management and dissemination of information (Ishizaki \& Kato, 1998; Katagiri, Takanashi, K., Ishizaki, Den, \& Enomoto, 2013)

In general, communication is instantaneous: the agreement on the remission-reception of meanings is spontaneous and, most of the times, tacit. The "agreement" is invoked only in case of disagreement. As Petra Hendriks shows, there are „speaker meanings” and „hearer meanings" and sometimes the two do not coincide. Under these circumstances, in order to find a solution, we make use of literal meanings: „Literal sentence meanings result from hearer's failure to calculate the speaker meaning in situations where the hearer's selected 
meaning and the speaker meaning differ. Similarly, non-recoverable forms result from the speaker's failure to calculate the hearer meaning in situations where the speaker's intended meaning and the hearer meaning differ." (Hendriks, 2010, p. 1). The meaning proves to be not only a construction, but also a co-construction (Tshesane, 2001; Maior, 2009; Angelopulo \& Barker, 2013).

The elements of this level irradiate also the message level: without being purely automatic, the emergence of the message is irrepressible. Meanings and messages are irrepressible and auto-telic. Instead, communication is dependent on the two poles of crystallization; it is a building that is built through the communicational commitment of the transactant. There are random meanings, but there is not incidental con munica. Communication is not unconscious or involuntary. It does not happen accide lly. There no involuntary communication. Any communication requires an im ici explic commitment. Shortly, communication is a commitment. Or commitmer is a volt ry cit. So, all communication is conscious and voluntary. Communication in lves a smmit ont to do jointly, to share something, achieving something together and $s^{1}$ rru acing it common includes the obligation to do voluntarily in common, being ir ormed. is ommon is preliminary, somehow individually, subjective, but not rand m eanings a sometimes be random, whereas communication can never be random. mmu tion is a negotiation, a transaction, and a negotiation cannot be involuntary. In com nunicat "silence and speech" constitute the object of communication (Nakane, 200 ; Fourie, 2010; F/unză, 2014).

At the first level of human will, we have the eanings. On the second level, we retain the message, and on the third level, we record vmunicati on. In more precise terms: meanings are unconditional, they are generated spom 4 . Meanings are spontaneous: the world emanates "sponte sua" meanings. montaneous includes the random. Some of the meanings precipitate, crystallize in mea ing an ational nuclei called messages. The messages seem irrepressible, but they are ot anymore unconditional: the message is conditioned by a receptor, a reciver, availa le communicator, by another. The meanings only need me. The message d rate needs me (assumed or real) and also an indispensable other real and computatio (Craft \& Davis, 2013). At the third leve communic n is double conditioned. It takes the condition and the message criterion al ad he additio al criterion of minimum confirming the sharing or at least certain mess ac mean In communication, the criterion of the message another is doubled by the making of co cron criteria, placing in common, sharing. If I and Thou (Another, $\mathrm{O} r$ ) are $\mathrm{p}$ tting in common meanings, even divergent, para-consistent, vague or contradicto, canings hen there is no communication. For meanings, it is enough also a simple Thou necessary for a real message. Martin Buber is he who in the philosophy of $g$ mmu cation $\mathrm{c}$ olishes the nuclear tandem of the communication "I and Thou", I and bim $T$ Tommunication, it is required that $I$ and Thou do something in common, to build ut in common spiritual or material meanings. H.-G. Gadamer contends that "the commun "nal relationship" has " the meaning of address" (Gadamer, 2000, p. 699).

In their situation of theoretical representations of human relationships, social relationships do not stop to be occurrences of existence. „The fundament of a social relationship (also its circumstance), asserts Professor Ilie Bădescu, is life manifestation that includes at least two individuals" (Bădescu, 2010, p. 279). Social relationship is, ontological, a life manifestation that attracts the action, interaction, and change of minimum two agents. The first feature of communicational relationship is that of being an existential manifestation. The life manifestation is meaning to be in the world, „being-in-the-world". Selfunderstanding and world understanding take place in relational terms. In fact, the social 
universe is a system of personal, interpersonal, social relationships (Munteanu, 3013; Siminică \& Traistaru, 2013; Avram \& Traistaru, 2014).

The human being perceives himself as element of a system and as an actant within this system. „Being-in-the-world, asserts Jurgen Habermas, is a fundamental ontological concept; its central significance here is as term of relatedness, it concerns our relations as persons (...) intrinsically related to our capacity for self-understanding and self-expression. We understand ourselves as actors or as agents in relation to the world" (Habermas, 1970, p. 35). Not only in the social system, is the individual agent or actor, additional in his consciousness and in his social manifestations, but he conceives himself as agent or actant and he behaves oncesuch. The agent's energy comes from his social relationship. His role and place $i$ the 1 structure of membership is fixed, first of all, by canonical sets of relatio hips. Jurg Habermas uses also the actor concept, also the agent concept. Craig Calhnu $u$ the act concept and considers ,social relationships” as being „the concrete conp ctions am sor al actors" (Calhoun, 1992, p. 206). Anthony Giddens chooses "Agent A ncy" iddens 4984, p. 5). Instead, professor Paul Dragoş Aligică uses ,,agents” (Aligi aside Pierre Bourdieu and Dumitru Batâr, he chooses the ,ag it" conco (Batô, 2003, p. 49).

\section{b) The numerical aspect}

The fourth criterium is found in number. $\mathrm{Tb}$ quantitative sta dard of the social is constituted by minimum two agents who interact, tr sact. The cemmunicational relationship is performed between two subjectivities, but it h inter-subj ctive character (GoodwinDavey \& Davey, 2000; Barker, 2009). This leads to L. ierre Bourdieu shows, that the „social world" is formed ,as a space riective relations” (Bourdieu, 1990, p. 8). Composing a relationship universe, social elat on are structured as ,a network of relationships", P. Bourdieu asserts (Bourdieu, 90, p.244).

\section{c) The transactional aspect}

Personal relationship nd relationship, we emphasize, they are also relationships. Their pra cal esse is constituted by action, interaction, connection and exchange, in a wo a: nsaction. ne communicational relationship is transactional (Sonderling, 1995 S nder 1996; Sonderling, 2012). Some authors consider, unilaterally, that a relation ip is define ther as action, or as interaction, or as exchange. The relationship erivati from action we find it, for example, with Max Weber. In his conception, th $\mathrm{o}^{\prime}$ action here is understood that behavior of an actor to which this attaches a meanin (,,atto s" a neaning): „Action is social insofar as its subjective meaning takes acceant o he beh. I of others and thereby oriented its course" (Weber, 1978, p. 4). J. No. ju annroaches that in Max Weber's work „Economy and Society”, and states that "the ept on ocial relationships is introduced via the concept of social action" (Mucha, 2003, p. Although in the theory of social relationship, A. Schutz starts from the „social action" of M. Weber and F. Znaniecki, his position is that social phenomena could be understood and explained according to a system of four reference schema having in center: „social relations, social group, social act and social personality”. Professor Raymond Boudon considers that action is in the core of social life and institutes social phenomena understanding within its original formula named ,,action sociology paradigm” (Boudon, 2006, p. 23). A. Schutz constructs a prototype of social relationship in a center where to fix the connection: „the prototype of all social relationship is an intersubjective connection” (Schutz, 
1971, p. 14). R. N. Lebow, for example considers that „social relations are characterized by exchange" (Lebow, 1996, p. 1).

Social interaction does not only generate basic communicational relationships, it can, as Nelson Goodman shows, „bring and lead to new social relationships" (Goodman, 1998, p.138). Alan Page Fiske, on the other hand, places at the basis of social relationship the interaction and demonstrates that ,people in all cultures use (...) relational models to generate most kinds of social interaction evaluation, and effect"; ,people interact with others in order to construct and participate in one or another of the four basic types of social relationships (Fiske, 1992, p. 689). In Professor Marian Preda's opinion, social interontion is substantial and it can be approached in processes as communications, confli $\mu$, dec, power or organizational exchange (Preda, 2006, pp. 32-46).

Social life is transaction and, so, directly, a communicational relationsh veb. O opinion is that the human being is the result of a long evolution $g^{f}$ interactio so al relating. He isn't impregnated socially, he is socially constructed. $T$ re is y huma seing outside the social, and social means, first of all, relationship eb. 2009; B răoanu, Negrea \& Dascălu, 2010; Balaban, 2013; Louw, 2014). J elating, nan oeings are performing their own essence. The fact that they expect a re at ship, they at to relate to one another or they must relate and to be engaged in rela onsh, which sometimes seem compulsory represents only an essence conversion in ensurtial neco Human being can be un-relational. His own relationship essence make him feel the nece, sity for a relationship. Hence, he has is inclined to engage in a relationshil MaCliam \& Barker, 2009; Creţu, 2009; Frunza, 2011).

A. P. Fiske observes that the whole social life or

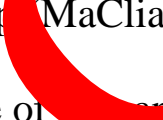

\& Barker, 2009; Creţu, 2009; „may be organized by combinations of ju elementary models (schemata, rules, or grammars): communal sharing, authority ra kin, dity matching, and market pricing" (Fiske, 1992, p. 690). The relational life of the world can be described, explained and understood through action of th se ty forms f relationship. Fiske specifies the content of these four models: „In con al aring, people treat all members of a category as equivalent. In authority $r$ ing, opmand to their positions in a linear ordering. In equality matching, peor keep tra fimbalances among them. In market pricing, people orient to ratio valy s" ke, 1994 p. 689). We understand that transaction (action, interaction, exchy) con ytes the third criterion of communicational relationship definition.

d) The repo ve, cerati aspect

As uide our o Mary coherence of knowledge, in concept, the content of standard and re गng trans. The etymological kernel of ,relationship” word provides us, additionally, with a ch ion necessary for the comprehension of a standard social relation. As repeated relation, th communicational relationship has at least two returning points. On the one hand, a relationship is conveyed from a person to another person. On the other hand, a relationship conveys backward. The persons who enter in a relationship are the terminus places of the relationship. As such, the relationship connects two returning places. There is no relationship without a return place. If it isn't responding to an interaction gesture, it isn't associated to a relationship. Communicational relationships have iterative character. Returning, replication, answer reaction forms the second criterion for a relationship. A relationship is the 
consequence of a relating. Under this standard, a relationship is a correlation (Creţu, 2009; Colhon \& Tandareanu, 2010; Brie \& Horga, 2010).

But the repetitive character is only a premise for a standard communicational relationship. Additionally, out of this, on an informational-organizational coordinate, any communicational relationship is loaded by an order that has two components, coherence and systemicity. Coherence is an oriented continuity. Sistemicity is referred to as relationship performing, not as its content (Dobrescu \& Bârgăoanu, 2001). Hence, there can be accepted a definition of the communicational relationship according to the organization idea as being relevant for re-launching intercession of a standard definition.

\section{CONCLUSION}

The standard communicational relationship is a transactional ap unitar nform. onal, coherent, iterative and systematic existential manifestation of two m abjecti ties. The ontological dimension assures existence of the relationsh . Instea the rganizinginformational dimension assures the relationship agai $1 \mathrm{~s}$ olatility, assures its crystallization, structuring, functioning. On systemic featur of an cial relationships there are pointed out structures of communicational relatio subseq communicational relationship structuring we can lk about social groups, organizations, social networks. We understand the communi tional relalonship as an existential meaningful manifestation with an interpersonal-itera transact onal character.

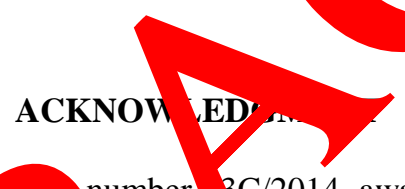

This work was partially supported by th number $3 \mathrm{C} / 2014$, awarded in the internal grant competition of the University of Craiova.

\section{References}

[1] Hendriks P. E). Emp al gvidence for embodied semantics. In Logic, Language and Mear.hg ( $\mathrm{p}$ 1-10). Sp nger Berlin Heidelberg.

[2] A. Borom Mernat nal Letters of Social and Humanistic Sciences 11 (2014) 1-168.

[3] N., Nu iating silence and speech in the classroom. Multilingua-Journal of cross iultural y d Interlanguage Communication 24(1-2) (2005) 75-100.

[4] A car. 2007). Prophecies of doom and scenarios of progress. Continuum Inte. tional Pub. Group.

[5] Batâr D. (2003). Sociologie. Sibiu: Editura Psihomedia.

[6] A. Borowski, International Letters of Social and Humanistic Sciences 4 (2013) 70-74.

[7] T. Lis, P. Bajdor (2013). Sales Logistics as a Model Used by Companies Fulfilling Individual Customer's Needs. In: Challenges in Contemporary Management. Monograph. Scientific Editors Anna Lemańska-Majdzik, Piotr Tomski, Sekcja Wydaw. WZ PCzęst, Czestochowa. 
[8] Bădescu I. (2010). Relaţiile sociale. Spaţiul dens. Noi teorii asupra relaţiilor sociale. In D. Otovescu (Coord.), Tratat de Sociologie Generală. Craiova: Editura Beladi.

[9] R. Barker (2012). Social networking and identity, Chapter in: The Handbook of Research on Technoself: Identity in a Technological Society. IGI-Global (www.igi-global.com/ijt).

[10] Boudon R. (2006). Acţiunea. In R. Boudon (Coord.), Tratat de sociologie. Bucureşti: Editura Humanitas.

[11] Kinga Dziwańska, International Letters of Social and Humanistic Sciences 7 (2013) 96-112.

[12] Bourdieu P. (1990). In other words. Stanford: Stanford University Press.

[13] Calhoun C. (1992). The infrastructure of modernity: indirect social information technology, and social integration. In H. Haferkamp

[14] W. Louw (2014). Designing Learning Experiences to Prepa c D.felo Learne s for the Complexities of the Workplace. In Psycho-social Caree ta-capact. 307-319). Springer International Publishing.

[15] Giddens A. (1984). The Constitution of Society.

[16] Goodman N. (1998). Introducere în sociologie Bucureşti: Editura Lider.

[17] M. Tshesane, Crime Research in South Africa (2001)

[18] Lebow R. N. (1996). The art of barga Londonn Hopkins Universit Press.

[19] Mucha J. (2003). The concept of social $r$ tions a classic analytical in classic analytical interpretative so wom . Webe, and Znaniecki, 6th ESA Conference-Murcia 2003, Research Network o 21 sp. 1-21.

[20] A. Borowski, Interng comal L rs oj social and Humanistic Sciences 2 (2014) 110-121.

[21] Preda M. (2006) a vortamen ǵanizaţional. Iaşi: Editura Polirom.

[22] Schutz A. (1). The il World and the Theory of Social Action. The Hague: Martinus Nijhoff.

[23] Teodor A (1998 Relaţia socială. In C. Zamfir \& L. Vlăsceanu (Eds.), Dicţionar de sociolo Bucur şti: Editura Babel.

[24 Web M. (19) Economy and Society. University of California Press.

[25] Journal of Management and World Business Research 6(1) (2009).

[26] J. M Vliam, R. Barker, Communicare 28(1) (2009).

[27] Otovescu D., Păsătoiu F., Petcu R. (2010). Grupurile social-umane, în Otovescu D., (Coord.), Tratat de Sociologie Generală. Craiova: Editura Beladi.

[28] N. Iancu, Revista Română de Studii de Intelligence 05 (2011) 124-136.

[29] S. Sonderling (1995). Historical research in communication, in Du Plooy, G.M. (Ed) Introduction to communication, Course Book 2: Communication research. Cape Town: Juta. 
[30] A. Borowski, International Letters of Social and Humanistic Sciences 3 (2013) 69-74.

[31] G. C. Angelopulo, R. Barker (2013). Integrated Organisational Communication. 2nd Edition. Cape Town: Juta

[32] Bârgăoanu A., Negrea E., Dascălu R., Journal of Media Research 3(1) (2010).

[33] S. Sonderling (1996). Language, in Fourie, P.J. (Ed) Introduction to communication, Course Book 3: Communication and the production of meaning. Cape Town: Juta.

[34] Delia Cristina Balaban (2013). Development of Communication Science in Romania. Challenges and Perspecives. Professional Communication and Translation

[35] Sandu Frunză (2014). Advertising and Administration under the Pressur Ethics. Le Arcs: Editions de la Suers.

[36] P. J. Fourie (Ed.). (2010). Media studies: media history, media an sociê (Vol. suta and Company Ltd.

[37] A. Borowski, International Letters of Social and Humanis c Sclence. (201, 70-74.

[38] M. Brie, I. Horga, Eurolimes 9 (2010) 155-171.

[39] D. F. Du Plessis (Ed.). (2001). Introduction to Py and Company Ltd.

[40] R. Barker (2003). Connecting to culture, Chap in: Strateg c organizational communication: paradigms and paradoxes. He nann: S ndown.

[41] G. C. Maior, Revista Română de Studi telligence 01-02 (2009) 5-8.

[42] A. Borowski, International Letters of So ialana , amanistic Sciences 6 (2013) 86-90.

[43] Marioara Avram, Aurelia Trut Intern tional Letters of Social and Humanistic Sciences 13 (2014) 79-8

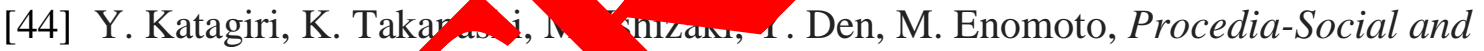
Behavioral Scieng 97 (2013) Q-428.

[45] N. Munteanu (13). Influence of Media Communication on the Military Organizati mo Buletin s tific.

[46] Sandu unza, vista de Cercetare şi intervenţie socială 31 (2011) 155-171.

[47] S. Sonder Comn inicatio 38(1) (2012) 64-83.

[481 A. O dwin-b y, C. Davey, Progressio 22(1) (2000).

[49] aichal Kolcun, Sebastian Kot (2014). The role of information systems in nsport logistics. International.

[50] M. Is Zaki, T. Kato (1998, August). Exploring the characteristics of multi-party dialogues. In Proceedings of the 36th Annual Meeting of the Association for Computational Linguistics and 17th International Conference on Computational Linguistics-Volume 1 (pp. 583-589). Association for Computational Linguistics.

[51] Stefan Freytag, International Letters of Social and Humanistic Sciences 10 (2013) 25-31.

[52] Ioana-Narcisa Creţu (2009). Introducere în ştiinţele comunicării. Note de curs. Sibiu. Editura Universităţii Lucian Blaga. 
[53] Marian Siminică, Aurelia Traistaru, International Journal of Education and Research 1(12) (2013).

[54] S. Craft, C. N. Davis (2013). Principles of American Journalism: An Introduction. Routledge.

[55] P. Dobrescu, A. Bârgăoanu (2001). Geopolitica. Fac. de Comunicare şi Relaţii Publice" David Ogilvy".

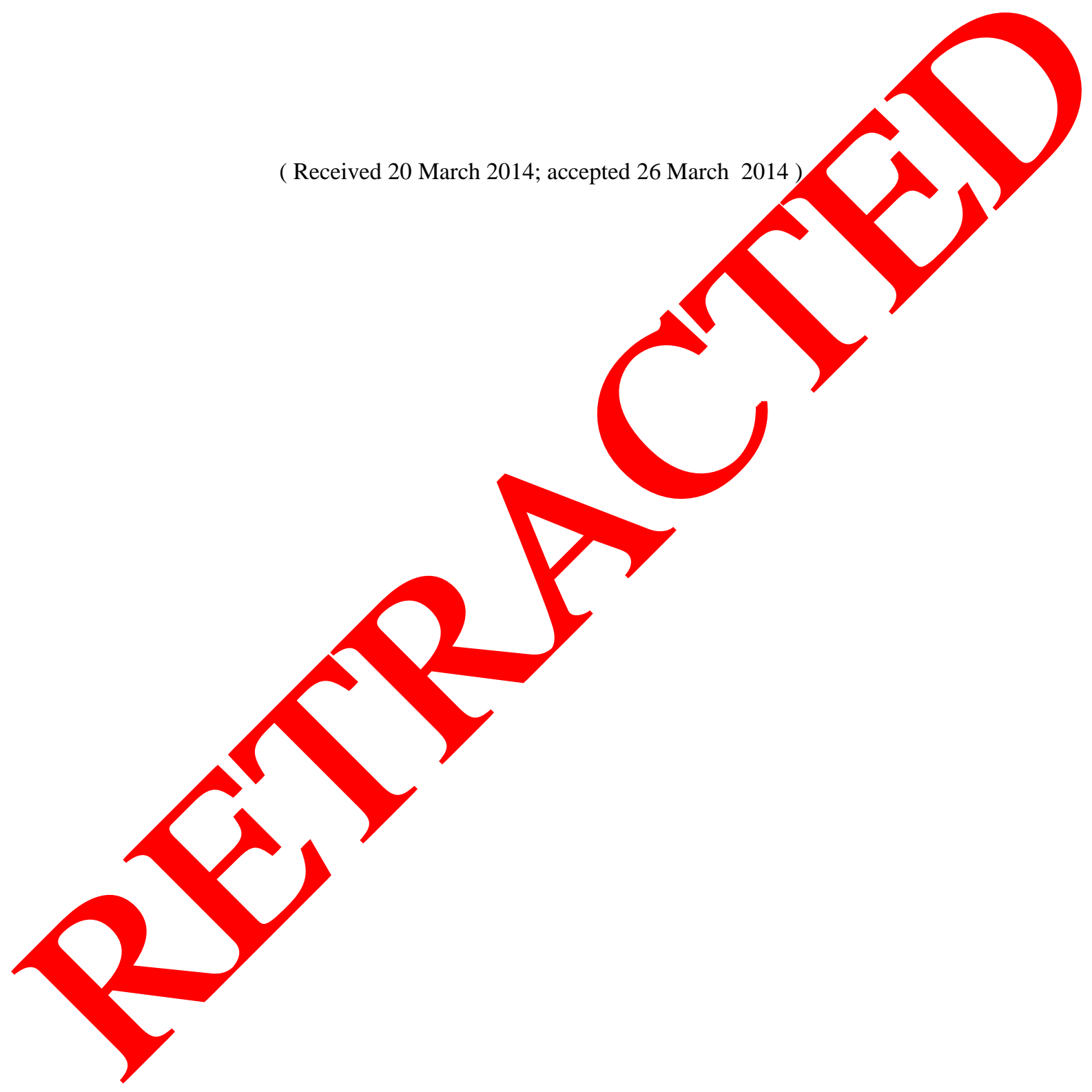

